\title{
Impact of Agricultural Exports on Agricultural Economic Growth in Ecuador: Case of Banana and Cocoa
}

\author{
Belen Apolo* \\ Agricultural Information Institute, Graduate School of Chinese Academy of Agricultural Sciences, \\ Haidian, Beijing 100081, China
}

\begin{abstract}
The contribution of this paper is to investigate the impact of agricultural exports on agricultural economic growth in Ecuador with the case of banana and cocoa. Annual time series data from the period between 1987 to 2017 was tested applying some econometrics techniques such as: Johansen co-integration test, Vector Auto Regression Model and Granger Causality test. The findings show there is no long run relationship between agricultural exports and agricultural economic growth on Ecuador, positive results were found in the short run regarding with banana exports, cocoa exports and agricultural capital formation It is concluded that policies should be implemented which aim to increase the quality and productivity of these crops.
\end{abstract}

Keywords: Agricultural economic growth, Banana exports, Cocoa exports

DOI: $10.7176 / \mathrm{JESD} / 11-12-04$

Publication date:June 30th 2020

\section{Introduction}

Ecuador has shown the importance of the agricultural sector in the national economy and has been closely linked to periods of boom and export crisis. The introduction to the international market began with the cocoa boom in 1880, which resulted in a 2.5 per cent increase in GDP (World Trade Organization, 2014). For the last 16 years the agricultural sector has grown irregularly at an average annual rate of $4.0 \%$. In the period 2000-2006 the average share of agricultural GDP was $8.62 \%$ compared with $8.27 \%$ in $2007-2016$. This decrease is a result of deficient public policy, private and foreign investment, modernization of farming, low productivity levels in agriculture. From 2003 to 2005, interannual growth was $5 \%$, due to growth in commodity prices on the world market, investment and consumption. Between 2006 and 2008, the growth of agricultural GDP decreased from 4\% to $1 \%$ (Banco Central de Ecuador, 2016).

Banana and cocoa exports have generated very significant income for the country's economy; however, the international trade of these products is faced with current regulations that affect the development of the activity, these two products agricultural activity generates direct employment and there are approximately 100,000 producers. This chain occupies a preferred position in Ecuador's economic context, as food and beverage manufacturing are a key activity in the national industry (PROECUADOR, 2016).

Exports of agricultural products have contributed on average with $30.6 \%$ of total exports in the period 20002006 with $29.7 \%$ in the 2007-2016 period. Agricultural exports have a lower level of stability than total exports; in the period 2014-2015 the increased was only $0.56 \%$. The outlook is similar in 2016 it had a growth of $0.61 \%$ of the FOB value since the percentage of exportable tonnes decreased by $-2.72 \%$. Total exports for the years 2015 and 2016 reduced by 16.320 million dollars, compared to the value of exports in 2014. In the same period, agricultural exports also decreased by USD 1.026 million (PROECUADOR, 2016).

In the rural sector, the unemployment rate has grown considerably and the sectors that depend on the agricultural sector have been affected. Government policies have focused on seeking alliances with markets such as the European Union through the Multiparty Common Agreement, as well as strategic alliances with China, which allow for greater internal investment and allowing Ecuadorian exports to reach new markets with more competitive prices (Franco,2018). The objectives of this paper include to investigate the role of agricultural exports in the Ecuadorian economy. Then, determine the impact of banana and cocoa exports on agricultural economic growth. Furthermore, this study will lead a better understanding for future research to propose policies recommendations and agricultural trade reforms to improve the efficiency of agricultural exports in relation to banana and cocoa.

\section{Agricultural exports led economic growth}

As Johnston and Mellor (1961) argued, expanding agricultural exports are one of the most promising ways to increase revenue. In a global environment where attention to the agricultural sector is reduced, it is important to measure the impact of agricultural exports on economic growth in a developing country. To explain the impact of agricultural exports on economic growth even in less developed countries Sanjuán-López and Dawson (2010) analyzed the role of agricultural exports in economic growth using the co-integration test for 42 developing countries they demonstrated a term relationship existing between agricultural exports and economic growth based on the results obtained by the authors. 
Dawson (2005) based his study in two models on agricultural production with the agricultural exports and non-agricultural exports. In each model, the fixed and random effects were estimated using panel data from sixtytwo less developed countries from 1974 to 1995, the study provided evidence from less developed countries supporting export-led growth theory. The results underlined the role of agricultural exports in economic growth and suggested a balanced export promotion policy. Edeme, Ifelunini et al. (2016) applied the Classical Solow Growth model and the Hausman test model to examine the impact of agricultural exports on economic growth in 15 Africans countries using panel data for the period 1980-2013. Furthermore, the results of this analysis show that agricultural exports had an insignificant individual impact on the economic growth of Africans countries, despite the country - specific impact, agricultural exports had a major impact only on economic growth in Liberia. Among the combined effects, the participation rate of agricultural exports and labor forces had a significant positive effect on economic growth, while capital stocks, non-agricultural exports and inflation were insignificant and had a negative impact.

The results presented by Ohlan (2013) indicate the positive relationship between the variables in the long-run and explained how agricultural exports play an important role in the increase of India's GDP. Ojo, Awe et al. (2014) examined the relationship between agricultural exports and economic growth using Johansen's multivariate co-integration analysis for the period 1980 to 2012 and the results explained that agricultural exports are long-term determinants of economic expansion. The study recommended that Nigeria's government direct efforts in the country's economic growth process to improve agricultural exports.

Ijirshar (2015) realized an empirical study using the co integration test to analyze the effects of exports on economic growth in Nigeria with statistical information from 1970 to 2012. The results explained the positive relationship between exports and economic growth in the long run equilibrium. In the same venue the results presented by Ali and Koko (2018) confirmed the existence of a positive relationship between the variables according to the results obtained in the analysis with period data among 1980-2010, which means that a unit increase in agricultural exports would bring more than a proportionate increase in Nigeria's Real Gross Domestic Product.

\section{Ecuadorian banana exports overview}

Orozco (2017) argued the banana boom was a period of great export growth that resulted in prolonged sustained growth due to the great commercial demand of the United States and Europe because the countries of Central America were experiencing an unfavorable climatic situation that is why it has become the world's largest banana exporter. Therefore, the GDP assessed at constant prices between 1948 and 1954 rose by 5.6 percent annually, between 1954 and 1965 by 4.8 percent, and between 1965 and 1970 by 5.2 percent.

The study presented by Abaza and Jha (2002) analyzed the impact of international trade policies on banana exports, variations have existed since the 1990s. There was a noticeable decline in export volume and a decline in international prices, this event was in 1993. According to Ramon and Rodrigo (2015) one of the problems faced by banana exports is the lack of commercial agreements that favor the entry of this product, especially to the European Union. There has been a disadvantage before the main competitors and the payment of tariffs is much higher.

In the report presented by AEBE (2018) the main destinations of banana exports in 2017 was Russia Due to the increase of demand of bananas in Russia, $24 \%$ of the total of shipments which is equivalent to 1.48 million of boxes are made to this country which has been considered as the first export destination during the last three years. It can also be seen that an increase of $7.58 \%$ was perceived with respect to the previous year, after an agreement signed with the European Union. Despite having the main competitor to the Philippines in the Middle East, shipments made to this destination also showed a growth that represented $12.68 \%$ of total shipments. It should be noted that the situation has been different before the United States since approximately 16 million fewer boxes were sent.

\section{Ecuadorian cocoa exports overview}

Ecuador was the world's largest cocoa exporter until losing this status from 1880-1915 due to two diseases known as moniliasis and the broom of the witch. Between 1915 and 1930, production fell by $63 \%$ (from 40,000 tons to 15,000 tons). In the 1940s, new orchards were renewed and planted, either using seeds from the national cacao trees that had tolerated the diseases or crossing the national cacao with alien, trinitarian, criollo and genotypes from the high and low Amazons and the Orinoco, as a strategy to combat diseases, which gave rise to the current National Cacao Complex sui generis, which retain the floral flavor that characterizes it but behaves like a trinitarian cacao (ANECACAO 2015).

According to MAGAP (2013) approximately 600,000 people were directly linked to the cocoa production and export process, representing $4 \%$ of national economically active population and $12.5 \%$ of the agricultural economic population. There are 100,000 units of agricultural production and it has been estimated that at least 100,000 people would be employed a year, if at least one person is employed in each unit. However, there is a 
high variability in the intensity of labor use among various types of producers.

According to Beillard \& Vega (2017) the variation in metric tons corresponding to 2015-2016 was linked with the reduction that United States presented in the demand. This decreased by $58 \%$ due to a reduction in harvest and explain despite the disadvantage of Ecuador in terms of its competitive exports of cocoa due to the international overproduction and the climate changes affecting production. Exports increased by an annual average of $14 \%$ during the 2007-2014 period Exports reached totaling \$775 million in 2014, 42\% were sent to the United States, $27 \%$ to the European Union, $11 \%$ to Mexico.

The export earnings in 2016 were 216 million dollars with a total of 78 thousand metric tons of cocoa, representing a decrease of $15 \%$ compared to the previous year in which 253 million dollars were generated with a total of 78 thousand metric tons of cocoa, since 2015, a restructuring of trade agreements has been undertaken (Anecacao, 2016).

According to Anecacao (2017), with the aim of counteracting the losses reflected in the volume of exports caused by a gradual decrease in international price. The Exporting Sector Promotion Project has encouraged export shipments to 25 destinations. In 2017, the European Union's general system of preferences was consolidated with the Multiparty Trade Agreement, thereby benefiting from a 0 percent tax rate. It should be noted that cacao exports increased by 14.9 percent of non - agricultural exports in 2017, a growth that was reflected in GDP.

\section{Materials and Methods}

\subsection{Definition of variables}

The dependent variable is Agricultural Gross Domestic Product (AGDP) and the independent variables are Banana Export (BANX), Cocoa Export (COCX), Agricultural Capital Formation (ACF) and Agricultural Labor Force (ALF).

\subsection{Data and methodology}

This research used annual secondary data that it covers the period of 30 years from 1987 to 2017 . , time series data have been carried out on Stata 15.The AGDP is obtained from World Bank, Banana and Cocoa exports are obtained from Central Bank of Ecuador, the Agricultural Labor Force and ACF are obtained from FAOSTAT. In order to examine the contribution of agricultural exports (banana and cocoa) on Ecuador's agriculture economic growth was used different econometrical procedures followed for an econometric model. Since we are using nonstationary data to avoid spurious results the first step is to test the stationarity of the time series data using Augmented Dickey-Fuller (ADF) test. The next step is to calculate the optimal number of lag length before applying cointegration test. In the case of the absence of cointegration we proceed to apply VAR model which lead us to analyze the impact between the variables. Finally, Granger causality test is used to find the causal relation between the variables.

\subsection{Model Specification}

The theoretical framework of this study has adopted the model proposed by Solow (1956) and Swan (1956) which is represented by an aggregate production function in terms of labor and capital under the standard neoclassical conditions. Their model examined the impact of population expansion and the role of technology in growth, without neglecting balanced conduct or distortions, to explain the process of accumulation of knowledge in their assumptions.

According to Romer (1991) Solow's model proposes a model of balancing with endogenous technological change in which long-term growth is conducted mainly by the accumulation of knowledge of earning-maximizing, progressive, and dynamic agents. The model states that economic growth is determined not only by the labor and capital but also by the raw material that will be transformed during the production process until obtaining the final good, which can be consumed or invested. Solow-Swan's model claims that population growth rates and savings rates affect per capita income levels in the stationary state in different countries, so that those with higher rates of saving tend to have higher per capita income levels, and countries with higher population growth rates tend to have lower levels. The model states that save rates and population growth rates, affect per capita income levels in the stationary state of different countries, so those with higher rates of savings tend to have higher levels of per capita income, and those countries with higher population growth rates tend to have lower rates.

In this study we follow an economic growth model developed by Solow in 1956, which it follows the neoclassical growth theory and for a more accessible exposition is determined by Cobb - Douglas production function.

Where $\mathrm{Y}$ is output

$$
\mathrm{Y}_{t}=L K
$$

$\mathrm{L}$ is labor force

$\mathrm{K}$ is capital.

This equation is expressed in terms of conventional inputs, labor and capital. 
In order to derive a source of-growth equation to examine the impact of agricultural exports on Agricultural economic growth, we extend the equation by including agricultural exports of the commodities selected.

$$
\mathrm{Y}_{t}=f\left(L_{t}, K_{t}, B A N X_{t}, \operatorname{COCX}_{t}, \mu\right)
$$

Considering the neo-classical framework, we adapt the Cobb Douglas production function with all the variables and its expressed as follows:

$$
\operatorname{AGDP}_{t}=f\left(A L F_{t}, A C F_{t}, B A N X_{t}, \operatorname{COCX}_{t}, \mu\right)
$$

Where $\mathrm{AGDP}_{t}$ is the Agricultural gross domestic product and it represents the production of the agricultural sector in the economy at time period t, $A L F_{t}$ is the Agricultural Labour force, $A C F_{t}$ is the Agricultural Capital Formation, $B A N X_{t}$ Banana Exports ,Cocoa Exports $\operatorname{COCX}_{t}$ and $\mu$ is independent of the other explanatory variables and represents the error term.

In order to avoid the differences in the measurement units, the minimization of the of the gap between the variables should be considered.

The function can also be derived in a natural logarithm:

$$
\ln Y_{t}=\beta_{0}+\beta_{1} \ln A L F_{t}+\beta_{2} \ln A C F_{t}+\beta_{3} \ln R E R_{t}+\beta_{4} \ln B A N X_{t}+\beta_{5} \ln C O C X_{t}+\varepsilon_{t}
$$

$\beta 0$ it represents the constant term independently distributed

$\beta 1-\beta 5$ are the parameters of explanatory variables estimated in the model

\section{Results and Discussions}

Methods are performed to know the relationship between the dependent and independent variables, following as Agricultural Gross Domestic Product (AGDP), Banana Export (BANX), Cocoa Export (COCX), Agricultural Capital Formation (ACF) and Agricultural Labor Force (ALF).The tests performed are the unit root test, Lag Selection Criteria, Co-Integration, VAR model and Granger Causality Test.

\subsection{Unit root test}

Since most series have irregularities it is necessary to analyze the single root, which is a non-stationary series indicator. Several non-stationary time series may become stationary after differentiating multiple times. A stationary series of differences becomes stationary after successive differentiation while a steady series of trend becomes stationary after deducting an estimated constant and trend from it. For the development of this study Augmented Dickey fuller (ADF) was applied.

The stationarity of the variables is determined with the probability of two hypotheses: Null Hypothesis (H0) represents the variable has unit root or is not stationary. The Alternative Hypothesis (Ha) signifies the absence of unit root and is stationary. Whether the probability is less than 5 percent represents that Ho is rejected and Ha is accepted.

Table 1. Unit Root Test

\begin{tabular}{|c|c|c|}
\hline \multirow{2}{*}{ Variables } & \multicolumn{2}{|c|}{ Probability } \\
\cline { 2 - 3 } & At level & First Differences \\
\hline Lnagdp & 0.9343 & 0.0105 \\
\hline Lnacf & 0.7674 & 0.0170 \\
\hline Lnalf & 0.3992 & 0.0000 \\
\hline Lnbanx & 0.4485 & 0.0001 \\
\hline Lncocx & 0.8988 & 0.0004 \\
\hline
\end{tabular}

The results reported in table 1 show the variables LNAGDP, LNACF, LNALF, LNBANX and LNCOX were found not stationary at level value. The p-value at level is more than 5 percent meaning that the $\mathrm{H} 0$ cannot be rejected or the variables are not stationary. Meanwhile, the results in first difference show the variables are stationary. Since the variables are stationary, we proceed to calculate the optimal lag length before to test the cointegration.

\subsection{Optimum Lag Selection}

This step consists in calculating the number of lag more suitable which represents the selection of appropriate lag length. This procedure frequently follows the approach based on information criteria such Akaike information criterion, Schwarz information criteria and Hannan Quin information criterion. Thus, the study adopted lag number one as the maximum for the model. The results of table 2 show that the maximum number of lags included to proceed cointegration is lag number one. 
Table 2. Optimum Lag Selection

\begin{tabular}{|l|l|l|l|}
\hline Maximum Rank & AIC & HQIC & SIC \\
\hline 0 & -9.65528 & -9.58561 & -9.41334 \\
\hline 1 & $-9.00449^{*}$ & $-8.58646^{*}$ & $-7.55284^{*}$ \\
\hline 2 & -9.5856 & -8.81923 & -6.38557 \\
\hline 3 & -10.2566 & -9.14191 & -6.38557 \\
\hline 4 & -14.3905 & -12.9274 & -9.30973 \\
\hline
\end{tabular}

* Indicates lag order selected by the criterion

AIC: Akaike information criteria

HQIC: Hannan Quin information criteria

SIC: Schwarz information criteria

\subsection{Cointegration}

The cointegration can be examined by Johansen Test, procedure that follows the Johansen approach and is based on the measurement of two statistics which are the trace test statistic, and the maximum eigen value test statistic. The first one, indicates the value of likelihood ratio in the stochastic matrix, and the second one examines the null hypothesis and exactly number of cointegrating relations (Johansen,1981). The aim of this theory introduced by Granger (1981) is used to analyze all possible cointegrating vectors among the variables, individually nonstationary and explain the implication of the existence of long run relationship. The co-integration test includes Agricultural economic growth as dependent variable and the independent variables are ACF, ALF, BANX and COCX.

The results presented in table 3 indicate the absence of cointegration between the variables, this is because the trace statistic of 57.14 is not greater that critical value 59.46 at $5 \%$ level of significance, meaning that the Null Hypothesis for rank 1 fails to be rejected. Similar results were found in (Kumari, 2014). Thus, the findings take us to establish that long run equilibrium does not exist between the variables.

Table 3. Cointegration Johansen test

\begin{tabular}{|l|l|l|}
\hline Maximum Rank & Trace Statistic & $5 \%$ critical value \\
\hline 0 & $57.1443^{*}$ & 59.46 \\
\hline 1 & 35.6916 & 39.89 \\
\hline 2 & 20.0746 & 24.31 \\
\hline 3 & 8.1404 & 12.53 \\
\hline 4 & 3.4239 & 3.84 \\
\hline
\end{tabular}

* Indicates lag order selected by the criterion

\subsection{VAR model}

The results obtained from table 4 proved the existence of short run relationship among banana exports and agricultural gross domestic product. The $\mathrm{p}$ value of 0.033 has statically significant impact of agricultural economic growth, implying that for $1 \%$ increase in BANX there is a corresponding change in AGDP of $0.31 \%$. The probability of 0.063 corresponding to Cocoa exports (COCX) is significant at $10 \%$ level of significance, meaning that influence directly on $0.34 \%$ increase in AGDP. Moreover, agricultural capital formation (ACF) presented the expected sign with a probability of 0.031 significant al $5 \%$ level, meaning that the increase of 1 percent of ACF will lead to increase the AGDP in $0.468 \%$. The variable that presented an unexpected sign is agricultural labour force, the p-value corresponding to ALF show that is not significant and a variation in $1 \%$ will lead to decrease the AGDP in $0.77 \%$ which explains is not a significant for agricultural economic growth. The value of the multiple coefficient of determination is 0.446 , implying that about $0.47 \%$ of the total variations in AGDP are caused by the variations in agricultural capital formation. We found that cocoa export has the expected sign and the coefficient is related with agricultural capital formation, it means that cocoa exports have positive impact to agricultural capital formation, it represents an indirectly contribution on agricultural gross domestic product.

Table 4. Vector auto regressive model

\begin{tabular}{|l|l|l|l|l|}
\hline D_LNAGDP & Coef. & Stand. error & $\mathrm{z}$ & $\mathrm{P}>|\mathrm{z}|$ \\
\hline LnAGDP & 0.1700198 & 0.2182025 & 0.78 & 0.436 \\
\hline LnACF & 0.4688859 & 0.2168049 & 2.16 & $0.031^{*}$ \\
\hline LnALF & -0.777739 & 0.7366941 & -0.11 & 0.916 \\
\hline LnBANX & 0.3096041 & 0.1438827 & -2.15 & $0.033^{*}$ \\
\hline LnCOCX & 0.347067 & 0.072562 & 0.48 & $0.063^{* *}$ \\
\hline
\end{tabular}

$*$ and $* *$ denote the $5 \%$ and $10 \%$ level of significance 


\subsection{Granger Causality test}

The test proposed by Granger (1969) is based on gives information about the significance of a variable for another variable considering a long span of time. It indicates that given two variables Granger cause if the lagged values of the second variable will be helpful to predict the lagged values of the first variable and the lagged values of first variable are cause by changes in second variable, it means that past values of first variable explain the actual values of second variable, then, there is a bi-directional causality between those two variables.

In order to determine the direction of causality between agricultural exports and agricultural economic growth we proceed to the final part of this study applying Granger Causality test. If the lagged values of agricultural exports do not cause AGDP in Ecuador, then agricultural exports will never determine the future values of agricultural gross domestic product.

\begin{tabular}{|l|l|l|} 
Table 5. Granger Causality test \\
\begin{tabular}{|l|l|l|}
\hline Null Hypothesis (Ho) & Probability & Decision \\
\hline D(LNBANX) does not Granger cause D(LNAGDP) & $0.033^{*}$ & Reject Ho \\
D(LNAGDP) does not Granger cause D(LNBANX) & 0.955 & Do not reject Ho \\
\hline D(LNCOCX) does not Granger cause D(LNAGDP) & 0.632 & Do not reject Ho \\
D(LNAGDP) does not Granger cause D(LNCOCX) & 0.109 & Do not reject Ho \\
\hline D(LNACF) does not Granger cause D(LNAGDP) & $0.031^{*}$ & Reject Ho \\
D(LNAGDP) does not Granger cause D(LNACF) & 0.936 & Do not reject Ho \\
\hline D(LNALF) does not Granger cause D(LNAGDP) & 0.916 & Do not reject Ho \\
D(LNAGDP) does not Granger cause D(LNALF) & 0.846 & Do not reject Ho \\
\hline
\end{tabular}
\end{tabular}

* denote rejection of Ho at $5 \%$ level of significance

The results show in table 5 indicate that at 5 percent level of significance there is unidirectional causality relationship between banana export and agricultural economic growth, while AGDP not cause BANX. This result takes us to establish that variations in banana exports imply changes in agricultural economic growth. Also, agricultural capital formation causes variations in AGDP, meaning that null hypothesis is rejected since the probability indicates a value less that 5 percent. No causality relationship was detected from cocoa exports and labor force towards economic growth.

\section{Conclussion}

The aim of this research is to examine the effects of banana and cocoa exports on the agricultural economic growth in Ecuador over 30 years, an augmented neoclassical production function was implemented. Vector autoregressive model (VAR), Johansen Cointegration and Error Correction modelling approach. The present study concludes that the variables were found stationary after the first difference, therefore the time series data was able to calculate the cointegration applying Johansen Co-integration test using the optimal lag number. The cointegration test confirm the absence of long run equilibrium relationship between banana, cocoa exports and AGDP. Meanwhile, the results obtained from VAR (vector auto regressive model) determined that BANX and COCX have significant and positive impact on AGDP. In the same way Agricultural capital formation was found statistically and significant. The positive impact of the variables mentioned lead us to confirm the theory indicated in the theorical framework. The only variable that does not have impact is Agricultural labor force, has a negative and insignificant association with AGDP. The results of Causality Granger test suggest that only two variables presented causality relationship towards AGDP, banana exports and agricultural capital formation but only unidirectional causality was evidenced Therefore, it is pertinent to mention that agricultural capital formation showed positive results with the dependent variable and it is linked with cocoa exports, which implies that variations in ACF will predict variations in Agricultural economic growth and cocoa exports have an indirect effect on AGDP. It necessary to enhance cocoa exports due as long as they increase, agricultural capital formation will rise.

\section{References}

AEBE, 2018. Asociacion de Exportadores de Banano del Ecuador. Bananotas, pp. 1-54.

ANECACAO, 2015. Asociacion Nacional de Exportadores de Cacao-Ecuador. [Online] Available at: $\mathrm{http}: / / \mathrm{www} . A n e c a c a o . c o m /$ index.php/es/quienes-somos/historia-delcacao.

ANECACAO, 2016. Asociacion Nacional de Exportadores de Cacao-Ecuador. Sabor Arriba, pp. 1-36.

Aurangzeb, A. Z., 2006. Exports, productivity and economic growth in Pakistan: a time series analysis. Lahore Journal of Economics, Volume 11(1), pp. 1-18.

Dawson, P., 2005. Agricultural exports and economic growth in less developed countries. Agricultural Economics, 33(2), pp. 145-152.

Edeme, . K., 2016. A Comparative Analysis of the Impact of Agricultural Exports on Economic Growth of ECOWAS Countries. Acta Oeconomica Pragensia , 24(05).

Ehinomen, C. \& O. O., D., 2012. Export and Economic Growth Nexus in Nigeria. Management Science and Engineering, Volume 6(4), pp. 132-140. 
Esfahani, H. S., 1991. Exports, imports, and economic growth in semi-industrialized countries.. Journal of Development Economics, Volume 35(1), pp. 93-116.

Granger, C. W., 1969. Investigating causal relations by econometric models and cross-spectral methods. Econometrica: journal of the Econometric Society, pp. 424-438.

Hamdan, B. S., 2016. The effect of exports and imports on economic growth in the Arab countries: A panel data approach. Journal of Economics Bibliography, Volume 3(1), pp. 100-107.

Herzer, D., et al. , 2006. Export-led growth in Chile: Assessing the role of export composition in productivity growth. The Developing Economies, Volume 44(3), pp. 306-328.

Ijirshar, V. U., 2015. The empirical analysis of agricultural exports and economic growth in Nigeria. Journal of Development and Agricultural Economics, Volume 7(3), pp. 113-122.

Intriago, F. L. M., et al., 2018. Cadena de comercialización del cacao nacional en la provincia de Los Ríos, Ecuador. Revista Ciencia y Tecnología, Volume 11(1), pp. 63-69.

Johansen, S. , 1988. Statistical Analysis of co integration vectors. Journal of economic dynamics and control, Volume 12, pp. 231-254.

Kumari, D., \& Malhotra, N. , 2014. Export-led growth in India: Cointegration and causality analysis. Journal of Economics and Development Studies, Volume 2(2), pp. 297-310.

MAGAP, 2016. La política agropecuaria ecuatoriana: hacia el desarrollo territorial rural sostenible: 2015-2025, Quito: Ministerio de Agricultura, Ganadería, Acuacultura y Pesca.

Meyer, J. W., et al. , 1997. World society and the nation-state. American Journal of sociology, Volume 103(1), pp. 144-181.

Michaely, M. , 1977. Exports and growth: an empirical investigation. Journal of Development Economics, Volume 4(1), pp. 49-53.

Ojo, E. J., et al., 2014. Agricultural export and economic growth in Nigeria: A multivariate Johansen cointegration analysis. International Journal of Arts and Commerce, Volume 3(3), pp. 89-98.

Orozco, R. V. , 2017. El impacto del comercio del Banano en el desarrollo del Ecuador. Revista AFESE, Volume 53, pp. 53-59.

PROECUADOR, 2016. Análisis de las exportaciones agrícolas de Ecuador. [Online] Available at: http://www.proecuador.gob.ec

Sanjuán-López, A. I. and P. Dawson , 2010. Agricultural exports and economic growth in developing countries: A panel cointegration approach. Journal of Agricultural Economics, Volume 61(3), pp. 565-583.

Santos-Paulino, A. U. , 2002. Trade liberalisation and export performance in selected developing countries. Journal of Development Studies, Volume 39(1), pp. 140-164.

Shah, S. W. A., et al., 2015. Agricultural export and economic growth: A case study of Pakistan. Public Policy and Administration Research, Volume 5(8), pp. 88-96.

Singer, H. W. and P. Gray , 1988. Trade policy and growth of developing countries: some new data. World Development, Volume 16(3), pp. 395-403.

Swan, T. W., 1956. Economic growth and capital accumulation. Economic record, Volume 32(2), pp. 334-361.

Tyler, W. G. , 1981. Growth and export expansion in developing countries: Some empirical evidence. Journal of Development Economics, Volume 9(1), pp. 121-130.

Ucan, O., et al. , 2016. The relationship between export and economic growth in Turkey. European Scientific Journal, ESJ, Volume 12(10).

Uquillas, C. A. , 2008. El modelo económico industrial en el Ecuador. Observatorio de la Economía Latinoamericana, Volume 104.

Wang, M., 2009. Manufacturing FDI and economic growth: evidence from Asian economies. Applied Economics, Volume 41(8), pp. 991-1002.

World Trade Organization, 2014. World Trade report. [Online] Available at: http://www.wto.org 